\title{
Allometric equations to estimate carbon pool in soil and above-ground biomass in mangrove forests in Southeast Mexico
}

\author{
J. J. Guerra-Santos, R. M. Cerón, J. G. Cerón, A. Alderete-Chávez, \\ D. L. Damián-Hernández \& R. C. Sánchez-Junco \\ Centro de Investigación de Ciencias Ambientales, \\ Universidad Autónoma del Carmen, Mexico
}

\begin{abstract}
This paper reports the results of carbon stored in soil and aboveground biomass from the most important area of mangroves in Mexico with dominant vegetation of Red mangrove (Rhizophora mangle L.), Black mangrove (Avicennia germinans L.), white mangrove (Laguncularia racemosa Gaertn.) and button mangrove (Conocarpus erectus L.) in three sites located in the Atasta Peninsula, Campeche, Mexico. Samples were taken in 2009 and 2010 during the dry season from soils with high fertility. To determine tree biomass (AGB), allometric equations were used. Greater values of AGB were found for button mangrove $\left(253.18 \pm 32.17 \mathrm{t} \mathrm{ha}^{-1}\right)$ and lower values were found for Black mangrove (161.93 \pm 12.63 ), intermediate carbon storage were found in the other two species Red mangrove $\left.181.70 \pm 16.58 \mathrm{t} \mathrm{ha}^{-1}\right)$, and white mangrove $\left(206.07 \pm 19.12 \mathrm{t} \mathrm{ha}^{-1}\right)$. Carbon stored in soil at the three sites was measured in a range of $36.80 \pm 10.27$ to $235.77 \pm 66.11 \mathrm{t} \mathrm{C} \mathrm{ha}^{-1}$. The Tukey test $(\mathrm{p}<0.05)$ showed significant differences exist between Black mangrove and button mangrove. The button mangrove trees evaluated had a higher AGB compared with other species, and black mangrove trees have a relatively lower AGB, because they grow in hypersaline environments which reduce their development, while for buttonwood mangrove growing on higher ground, their soils are better able to obtain nutrients. AGB tends to be relatively low in areas near the sea and rise as the forest location is closer inland. In the case of a black mangrove, usually these individuals are growing on recently deposited sediments; the Tukey test indicated no significant differences among the sample sites. These results show that all sites have good potential to store carbon for long periods of time. The
\end{abstract}


carbon stored in the three sampling sites in the state of Campeche Mexico is higher than that reported by other authors in different places in the world.

Keywords: carbon storage, Rhizophora mangle, Laguncularia racemosa, Avicennia germinans, tree biomass.

\section{Introduction}

Carbon Dioxide $\left(\mathrm{CO}_{2}\right)$ is emitted to the atmosphere both naturally and anthropogenic, is the most important greenhouse gas and its large quantities contribute $55 \%$ of global warming The concentration of $\mathrm{CO}_{2}$ in the atmosphere has increased from $280 \mathrm{ppm}$ in 1750 to $367 \mathrm{ppm}$ in 1999 (31\%), the observed increase is predominantly due to the oxidation of organic carbon from burning fossil fuels and deforestation [1]; The main C stocks in forest ecosystems are soil, vegetation and humus, this is because the vegetation has the ability to assimilate carbon and incorporate it into its structure, to be fixed and stored for long periods of time, through photosynthesis. That is why forests are important carbon sinks [2]. The foliage of the trees adds organic matter to the soil when the leaves are decomposed; they incorporate $\mathrm{CO}_{2}$ into the soils then gives rise to stable humus which, in turn, brings again $\mathrm{CO}_{2}$ [3].

Wetlands are known to be an important carbon sink despite occupying only about $5 \%$ of the planet's surface, contain much of the reservoir of carbon stored in the world [4]; their soils stored carbon for a long period of time, due the phreatic groundwater, high productivity and low decomposition by the slow diffusion of oxygen [5].

Field studies for the determination of biomass and productivity in mangrove forests are quite difficult due to muddy soil conditions. There are 3 commonly used methods that have been developed to estimate forest biomass: 1) the destructive method, 2) the average tree method and 3) the allometric method; in mature forests, trees can reach up to several tons in weight, so in the destructive method, trees would be harvested for data, so it is not practical in these cases and is difficult to reproduce the results. The average tree method usually applies only in forests with a homogeneous distribution of sizes in the trees, as in the case of plantations (Komiyama et al. [4]); The allometric method on the other hand, is used to estimate the partial or total weight of a tree from measurable dimensions such as Diameter at Breast Height (DBH) and height of the individual, using allometric equations [6]. In this work it was decided to use this method because it has the advantage that it is not a destructive method and is therefore useful to estimate temporal changes in forest biomass through subsequent measurements, for instance the diameter of the tree is easily measured and the weight of the tree is much more difficult to determine, this alternative method is a relatively easy to estimate the biomass in forests

The state of Campeche ranks first nationally according to their protected area with the largest expanses of mangrove coverage, more than 259000 ha, are located in the area of protection of Flora and Fauna "Laguna de Términos" is considered the most important wetland area in the Gulf of Mexico. The Atasta Peninsula is located in this area, where different economic activities, such as 
agriculture, aquaculture, oil industry and population growth are the main threats to these mangrove forests [7]. Therefore, due to the ecological and economic importance of mangrove forests located in the study region, this paper reports results of the carbon stored in soil and tree biomass estimated from allometric equations in a mangrove forest located in the Peninsula Atasta in Campeche, Mexico.

\section{Methodology}

\subsection{Site description}

The study area is located northwest of the state of Campeche, is part of the municipality of Carmen, the geomorphology of the area consists of wetlands and floodplains at elevations between 0 and $20 \mathrm{~m}$. The soils of the region are characterized by heavy clay with high fertility and are associated with predominant vegetation of mangrove forest as Rhizophora mangle (Rm), Avicennia germinans (Ag), Laguncularia racemosa (Lr) and Conocarpus erectus (Ce) [7].

The climate regime of the area has three well defined seasons: dry (February to May), rainy (June to October) and "North" (November to February). The selected stations (Table 1) were as follows:

Puerto Rico (PR) located at $18^{\circ} 36^{\prime} 55^{\prime \prime} \mathrm{N}$ and $91^{\circ} 56^{\prime} 35^{\prime \prime} \mathrm{W}$, at an altitude of 11 meters. The classification of this is the type mangrove basin as described by Lugo and Snedaker [8], the plots are located inland, have a minimum slope of land and water turnover very slow floodwaters accumulate in depressions; to others, by its terms, these sites correspond according to Twilley et al. [9] to a cycle of organic matter and nutrients in a closed ecosystem; on this site were recorded Avicennia germinans, Laguncularia racemosa, and Rhizophora mangle.

Table 1: Description of study sites: mangrove species occurring, geographical coordinates, maximum diameter at $1.30 \mathrm{~m}$ (Max. $\mathrm{DBH})$, annual rainfall, duration of the dry season and forest type.

\begin{tabular}{|c|c|c|c|}
\hline & \multicolumn{3}{|c|}{ Study site } \\
\hline & Puerto Rico & Xicalango & $\begin{array}{l}\text { Nuevo } \\
\text { Campechito }\end{array}$ \\
\hline Species & Rm, Lr, Ag & Lr, Ag, Ce & Rm, Lr, Ag, Ce \\
\hline geographical & $18^{\circ} 36^{\prime} 55^{\prime \prime} \mathrm{N}$, & $18^{\circ} 37^{\prime} 02^{\prime \prime} \mathrm{N}$, & $18^{\circ} 38^{\prime} 28^{\prime \prime} \mathrm{N}$ \\
\hline coordinates & $91^{\circ} 56^{\prime} 35^{\prime \prime} \mathrm{W}$ & $91^{\circ} 58^{\prime} 20^{\prime \prime} \mathrm{W}$ & $92^{\circ} 27^{\prime} 29^{\prime \prime} \mathrm{W}$ \\
\hline $\begin{array}{l}\text { Maximum. } \\
\text { DBH }(\mathrm{cm})\end{array}$ & 49.8 & 2.93 & 7.80 \\
\hline $\begin{array}{l}\text { Rainfall } \\
\text { (mm/year) }\end{array}$ & 1680 & 1680 & 1680 \\
\hline $\begin{array}{l}\text { Months of the } \\
\text { dry season }\end{array}$ & 4 & 4 & 4 \\
\hline Type of forest & Wet mangrove & Wet mangrove & Wet mangrove \\
\hline
\end{tabular}


Xicalango (XC): located $18^{\circ} 37^{\prime} 02^{\prime \prime} \mathrm{N}$ and $91^{\circ} 58^{\prime} 20^{\prime \prime} \mathrm{W}$, at an altitude of 12 meters. The mangrove forest settled in this site corresponds to a mixed stunted mangrove as proposed by Rico-Gray [10]. On this site we found a mixture of mangrove species such as Ag, Lr and Ce, the plots were located inland near a stream that connects the lagoon system Pom-Atasta. The soil is yellowish brown and has high activity of aquatic fungi and bacteria, with a low concentration of salinity. It is a very dense mangrove, the height of the individuals ranged from approximately 3 to $6 \mathrm{~m}$ with exposed aerial roots that made complicated the access

Nuevo Campechito (NC) located $18^{\circ} 38^{\prime} 28^{\prime \prime} \mathrm{N}$ and $92^{\circ} 27^{\prime} 29^{\prime \prime} \mathrm{W}$, with a height of $1 \mathrm{~m}$. Like PR, the mangrove forest is the type of basin [8], grows in a coastal plain with poor drainage, selected plots were bordered by two small lakes, major mangrove species found were $\mathrm{Ar}, \mathrm{Lr}$ and $\mathrm{Ce}$

\subsection{Method of sampling and forest inventory}

Soil samples were collected at the three sites described above located in areas of mangrove forest Atasta Peninsula. The sample collection was conducted during the dry season in 2009 and 2010. Each site was chosen selectively, seeking representation in the region, considering factors such as vegetation, accessibility and hydrology. At each sampling site plots were $18 \mathrm{~m}^{2}, 6$ plots were established for the PR, and in NC and XC 3 plots at each site. In each of the plots were collected 3 samples distributed in a transect, taken at $0.30 \mathrm{~m}$ depth using a corer of $193.3 \mathrm{~cm}^{3}$, to include a variation of organic matter per site; After extraction, each sample was labelled, sealed and processed in the laboratory for analysis. The forest inventory was conducted in 12 plots of $200 \mathrm{~m}^{2}$ distributed in a rectangular shape in the three sampling sites. Data were recorded at $1.30 \mathrm{~m}$ in diameter (DBH) for all species, in the case of $\mathrm{Rm}$ the $\mathrm{DBH}$ was measured at $1.30 \mathrm{~m}$ above the adventitious roots and a total of 321 trees data were collected.

In the laboratory, samples were removed the shells, bits of organic material (roots, leaves and branches), then air-dried and passed through a sieve of $2 \mathrm{~mm}$. For quantification of Organic Carbon (CO) was used the method of loss on ignition, which consists in determining the organic matter by heating at $550^{\circ} \mathrm{C}$ for $4 \mathrm{~h}$ (Heiri et al. [11]) and converted to CO by multiplication with 0.4 (Craft et al. [12]).

\subsection{Analytical procedure}

To determine the bulk density (Da) a plastic tube assay was used, which consists in passing the dry sample through a sieve of $2 \mathrm{~mm}$; the weight of the plastic test tube of $50 \mathrm{ml}$ was obtained after that 20 to $50 \mathrm{~g}$ of sieved soil were added, then placed on a firm surface and given 30 strokes with a rubber mallet in a vertical path from 0.20 to $0.30 \mathrm{~m}$. Finally, record the volume occupied and the weight of the sample.

To calculate Carbon stored (CA) was carried out by the following eqn (1):

$$
\mathrm{C}=\mathrm{CO} \% \mathrm{X} \text { Da } \mathrm{X} \operatorname{Pr}
$$


where: $\mathrm{C}=$ carbon stored $\left(\mathrm{T} \mathrm{h} \mathrm{ha}^{-1}\right)$; CO\% = percentage of carbon in the soil, $\mathrm{Da}=$ apparent density $\left(\mathrm{t} / \mathrm{m}^{3}\right)$ and $\mathrm{Pr}=$ the depth (m) (Gonzalez et al. [13]).

The electrical conductivity (EC) was measured by a conductometer CL 35 in an extract suspended in a 1:5 soil: water solution (NOM-021-RECNAT-2001). Statistical development compares and relates the statistical analysis for carbon storage by compartment and EC data. The average values were obtained for the different determinations. The hypothesis made was evaluated by the method of one-way ANOVA to determine significant differences between sampling station and plots. The evaluation was conducted by testing standardization and homogeneity of variances ( $p<0.05$ ) by Tukey's method, using the Statistica software version 7 .

Allometric models were used to estimate tree biomass (AGB), these models were developed from destructive sampling for different mangrove forests around the world (Table 2), the model used in this study calculated with equation (2), is based on samples of a total of 2.410 trees of different tropical forests, including 27 study sites distributed in the tropics (Chave et al. [14]):

$$
\mathrm{AGB}=p\left(\exp \left(-1.349+1.980 \operatorname{Ln}(\mathrm{DBH})+0.207(\operatorname{Ln}(\mathrm{DBH}))^{2}-0.0281(\operatorname{Ln}(\mathrm{DBH}))^{3}\right)\right.
$$

where $\mathrm{p}$, is the density of the wood, and $\mathrm{DBH}$ is the diameter of the stems at breast height. This model assumes a constant ratio between the diameter and height, which is useful because the height of the trees was a missing data in our forest inventory. The density of the wood was extracted from the database Global Wood Density (Zanne et al. [15]). For species not included in the

Table 2: $\quad$ Allometric equations for estimating tree biomass (AGB in Kg) for mangrove forests with $\mathrm{DBH}=$ Diameter at $1.30 \mathrm{~m}, \mathrm{p}=$ wood density $\left(\mathrm{t} \mathrm{m}^{-}{ }^{3}\right)$. The densities are: Avicennia germinans $=900$, Laguncularia racemosa $=762$, Rhizophora mangle $=1000$, and Xylocarpus granatum $=700$.

\begin{tabular}{|c|c|c|c|}
\hline Equation & Specie & Area & Source \\
\hline $\mathrm{AGB}=0.140 \mathrm{DBH}^{2.40}$ & Avicennia germinans & French Guyana & $\begin{array}{l}\text { Fromard et al. } \\
\text { (1998) }\end{array}$ \\
\hline $\mathrm{AGB}=0.140 \mathrm{DBH}^{2.54}$ & Avicennia germinans & $\begin{array}{l}\text { Guadeloupe, } \\
\text { French Antilles }\end{array}$ & $\begin{array}{l}\text { Imbert and Rollet } \\
\text { (1989) }\end{array}$ \\
\hline $\mathrm{AGB}=0.102 \mathrm{DBH}^{2.50}$ & $\begin{array}{l}\text { Laguncularia } \\
\text { racemosa }\end{array}$ & French Guyana & $\begin{array}{l}\text { Fromard et al. } \\
\text { (1998) }\end{array}$ \\
\hline $\mathrm{AGB}=0.209 \mathrm{DBH}^{2.24}$ & $\begin{array}{l}\text { Laguncularia } \\
\text { racemosa }\end{array}$ & $\begin{array}{l}\text { Guadeloupe, } \\
\text { French Antilles }\end{array}$ & $\begin{array}{l}\text { Imbert and Rollet } \\
\text { (1989) }\end{array}$ \\
\hline $\mathrm{AGB}=0.178 \mathrm{DBH}^{2.47}$ & Rhizophora mangle & $\begin{array}{l}\text { Guadalupe, French } \\
\text { Antilles }\end{array}$ & $\begin{array}{l}\text { Imbert and Rollet } \\
\text { (1989) }\end{array}$ \\
\hline $\mathrm{AGB}=0.0823 \mathrm{DBH}^{2.59}$ & Xylocarpus granatum & West Australia & $\begin{array}{l}\text { Clough and Scott } \\
\text { (1989) }\end{array}$ \\
\hline $\mathrm{AGB}=0.251 p \mathrm{DBH}^{2.46}$ & Common & $\begin{array}{l}\text { Tropical Forest in } \\
\text { America, Asia, and } \\
\text { Oceania }\end{array}$ & $\begin{array}{l}\text { Komiyama et al. } \\
\text { (2005) }\end{array}$ \\
\hline $\begin{array}{l}\text { AGB }=p(\exp (-1.349+ \\
1.980 \operatorname{Ln}(\mathrm{DHB})+0.207(\mathrm{Ln} \\
\left.(\mathrm{D}))^{2}-0.0281(\operatorname{Ln}(\mathrm{DHB}))^{3}\right)\end{array}$ & Common & Southwest of Asia & Chave et al. (2005) \\
\hline
\end{tabular}


database is considered the density of the wood to any member of the same botanical family. The carbon content of the biomass was evaluated at $50 \%$ dry weight of biomass (Basuki et al. [16]).

\section{Results and discussion}

\subsection{Importance value}

In all sites the importance value (defined as the sum of the relative frequency plus relative density, plus relative dominance divided into 3) was calculated (see Table 3). In Puerto Rico (PR), A. germinans, had the highest importance value, and $\mathrm{L}$. racemosa the minimum value, similar results had been found for $A$. (NC) $L$. racemosa obtained the maximum value and even $A$. germinans germinans in plots located in other areas of Laguna de Terminos in mangrove forests of the river type (Day et al. [17]), in contrast in Nuevo Campechito corresponded to the minimum value of importance. Puerto Rico had the lowest density of trees; however, were found largest diameter trees and basal area. On the other hand, Xicalango (XC) had the minimum values of diameter and basal area, while in $\mathrm{NC}$, was the site with the highest density of trees. Note that in XC, the three species present (Ag, Lr and Ce) have the same value of importance shown in Table 3.

Table 3: Composition of trees in mangrove forests of Puerto Rico, New Campechito and Xicalango (trees $>1 \mathrm{~cm} \mathrm{DBH}$ ).

\begin{tabular}{|c|c|c|c|c|c|}
\hline Site/species & $\begin{array}{l}\text { Density } \\
\left(\text { stem ha }^{-1}\right)\end{array}$ & Frequency $^{1}$ & $\begin{array}{l}\mathrm{DBH} \\
\text { mean } \\
(\mathrm{cm})\end{array}$ & $\begin{array}{l}\text { basal area } \\
\left(\mathrm{m}^{2} \mathrm{ha}^{-1}\right)\end{array}$ & $\begin{array}{l}\text { Importance } \\
\text { value }^{2}\end{array}$ \\
\hline \multicolumn{6}{|l|}{ Puerto Rico } \\
\hline Avicennia germinans & 9050 & 78.06 & 11.09 & 13.31 & 78.06 \\
\hline Laguncularia & 1100 & 9.71 & 9.74 & 3.69 & 9.71 \\
\hline racemosa & 1400 & 12.23 & 11.33 & 1.77 & 12.23 \\
\hline $\begin{array}{l}\text { Rhizophora mangle } \\
\text { Total }\end{array}$ & 11550 & & & 18.77 & 100 \\
\hline \multicolumn{6}{|l|}{ Nuevo Campechito } \\
\hline Avicennia germinans & 2780 & 7.42 & 6.46 & 3.47 & 7.42 \\
\hline Laguncularia & 12220 & 33.83 & 2.49 & 2.37 & 33.83 \\
\hline racemosa & 7780 & 25.42 & 2.2 & 1.96 & 25.42 \\
\hline Rhizophora mangle & 10000 & 33.33 & 1.28 & 1.30 & 33.33 \\
\hline $\begin{array}{l}\text { Conocarpus erectus } \\
\text { Total }\end{array}$ & 32780 & & & 9.10 & 100 \\
\hline \multicolumn{6}{|l|}{ Xicalango } \\
\hline Avicennia germinans & 6667 & 33.33 & 1.64 & 1.41 & 33.33 \\
\hline Laguncularia & 13889 & 33.33 & 1.14 & 1.42 & 33.33 \\
\hline racemosa & 3333 & 33.33 & 1.19 & 0.37 & 33.33 \\
\hline $\begin{array}{l}\text { Conocarpus erectus } \\
\text { Total }\end{array}$ & 23889 & & & 3.2 & 100 \\
\hline
\end{tabular}




\subsection{Estimating tree biomass (AGB)}

The higher average of AGB was found in C. erectus $\left(253.18 \pm 32.17 \mathrm{t} \mathrm{ha}^{-1}\right)$ and lowest in $A$. germinans $\left(161.93 \pm 12.63 \mathrm{t} \mathrm{ha}^{-1}\right)$, species with intermediate tree biomass were R. mangle (181.70 $\left.\pm 16.58 \mathrm{t} \mathrm{ha}^{-1}\right)$ and L. racemosa (206.07 \pm $19.12 \mathrm{t} \mathrm{ha}^{-1}$ ) (Figure 1) Similar values were found for tree biomass (AGB) in a forest of Avicennia (193 $\mathrm{tha}^{-1}$ ) in Sri Lanka (Amarasinghe and Balasubramaniam [18]), and lower values (35.1 $\mathrm{t} \mathrm{ha}^{-1}$ ) in French Guyana, in the this study found similar data for Laguncularia associated with Avicennia (188.6 t ha ${ }^{-1}$ ) (Fromard et al. [19]), on the other hand, in India were found somewhat similar values for Rhizophora (214 $\mathrm{t} \mathrm{ha}^{-1}$ ) (Mall et al. [20]).

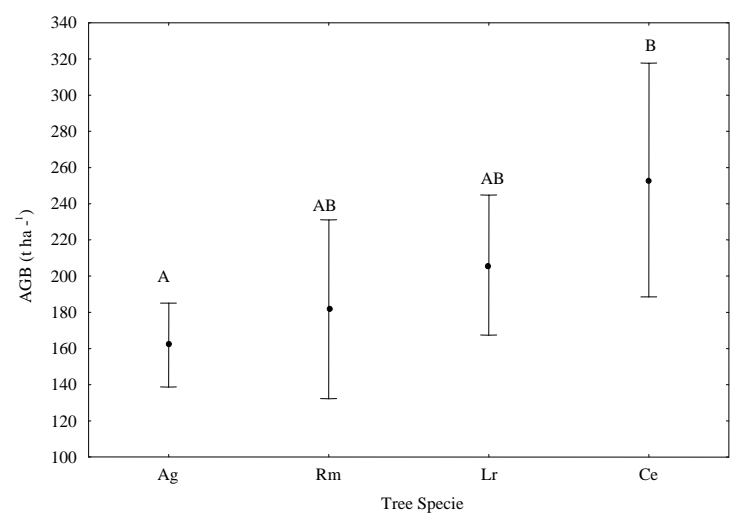

Figure 1: Mean values for the content of tree biomass (AGB/t ha ${ }^{-1}$ ) of the four species $(\mathrm{Ag}=$ Avicennia germinans, $\mathrm{Rm}=$ Rhizophora mangle, $\mathrm{Lr}=$ Laguncularia racemosa and $\mathrm{Ce}=$ Conocarpus erectus). Means with the same letter are not significant $\mathrm{p}<0.05$.

The Tukey test showed significant differences between Ag and Ce (ANOVA, $\mathrm{p}<0.05$ ), which means that trees of $\mathrm{C}$. erectus evaluated, had a larger AGB compared with other species, and trees of A germinans showed a relatively lower AGB, according to previous reports, this may be because the trees grow in hypersaline environments, which can reduce their development as proposed by Komiyama et al. [6].

While C. erectus grows up in higher areas, the soils have better conditions for nutrients. AGB tends to be relatively low in areas near the sea and rise as forest location is closer inland. In the case of A. germinans, these individuals are usually growing on recently deposited sediments, however, besides this factor, there are others such as soil properties and nutritional status (Komiyama et al. [4]) which may affect the rate of growth in biomass of mangrove forests.

\subsection{Carbon stored}

The Tukey test showed no significant variation in the carbon stored on site in both the AGB (fig 2) and soil (fig 3). However, for carbon in tree biomass, XC 
present the maximum value $\left(114.37 \pm 12.74 \mathrm{t} \mathrm{ha}^{-1}\right)$, while the minimum value was obtained in PR $\left(77.46 \pm 9.17 \mathrm{t} \mathrm{ha}^{-1}\right)$. In this case, measured trees had similar diameter sizes, the highest density of Ce was found in XC, which explains the increase recorded.

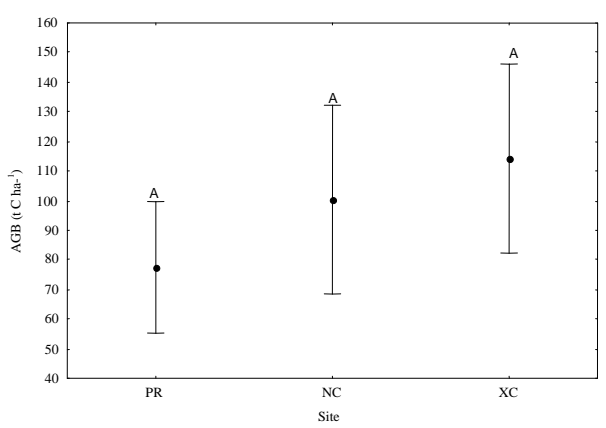

Figure 2: $\quad$ Mean values of carbon in tree biomass (AGB, t C ha ${ }^{-1}$ ) at different sampling sites. Means with the same letter are not significant $\mathrm{p}<0.05$.

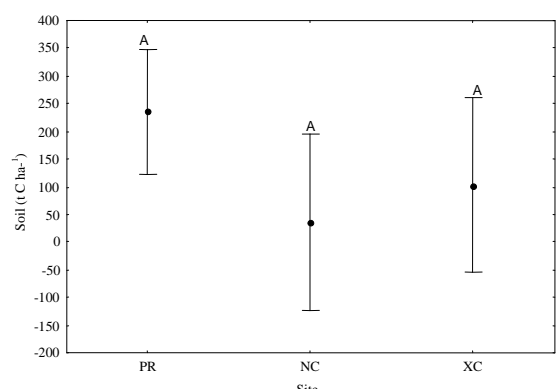

Figure 3: Mean values of carbon content in soil ( $\mathrm{C} \mathrm{ha}^{-1}$ ) at different sampling sites. Means with the same letter are not significant $\mathrm{p}<0.05$.

The carbon stored in the soil of the three sites was within a range of $36.80 \pm$ 10.27 to $235.77 \pm 66.11 \mathrm{t} \mathrm{C} \mathrm{ha}^{-1}$ showing superior performance to that reported by authors such as Arreaga [21] as well as Webb [22], the maximum value was found in Puerto Rico (235 $\pm 66.11 \mathrm{t} \mathrm{ha}^{-1}$ ) and the minimum value in Nuevo Campechito (36.00 \pm 10.27 ). The plots in Puerto Rico had the highest density of A germinans, a species that sits on land that has high organic matter accumulation due to low rates of decomposition in the soils by being continuously flooded and present high concentrations of salts also inhibit decomposition, this would explain its contents as high carbon in the soil and also its low forest development.

The carbon stored in AGB as shown in Table 4, differed significantly between forest plots ( $\mathrm{p}<0.05$ ), averaging $174.08 \pm 8.86 \mathrm{t} \mathrm{C} \mathrm{ha}^{-1}$ in mangrove 
Table 4: $\quad$ Mean of tree biomass (AGB), carbon content in AGB, and soils of mangrove forests at Atasta Peninsula, Campeche, México.

\begin{tabular}{ccccc}
\hline Site & Plot & $\begin{array}{c}\text { AGB } \\
\left(\mathrm{t} \mathrm{ha}^{-1}, \text { mean } \pm \mathrm{ES}\right)\end{array}$ & $\begin{array}{c}\text { AGB } \\
\text { ( C ha }^{-1}, \\
\text { mean } \pm \mathrm{ES})\end{array}$ & $\begin{array}{c}\text { Soil } \\
\text { (t C ha }^{-1} \\
\text { mean } \pm \mathrm{ES})\end{array}$ \\
\hline PR & P1 & $116.45 \pm 7.22$ & $58.22 \pm 3.61$ & $64.18 \pm 10.52$ \\
PR & P2 & $145.46 \pm 14.68$ & $72.73 \pm 7.34$ & $73.46 \pm 7.89$ \\
PR & P3 & $165.29 \pm 46.10$ & $82.65 \pm 23.05$ & $480.26 \pm 30.34$ \\
PR & P4 & $236.90 \pm 47.76$ & $118.45 \pm 23.88$ & $356.02 \pm 77.30$ \\
PR & P5 & $113.80 \pm 6.69$ & $56.90 \pm 3.34$ & $202.89 \pm 49.58$ \\
PR & P6 & $151.67 \pm 15.36$ & $75.84 \pm 7.68$ & $237.82 \pm 10.49$ \\
NC & P7 & $169.56 \pm 45.58$ & $84.78 \pm 22.79$ & $54.85 \pm 17.52$ \\
NC & P8 & $162.03 \pm 21.29$ & $81.01 \pm 10.64$ & $33.61 \pm 5.60$ \\
NC & P9 & $269.80 \pm 41.79$ & $134.90 \pm 20.90$ & $19.53 \pm 13.18$ \\
XC & P10 & $279.72 \pm 29.00$ & $139.86 \pm 14.50$ & $116.88 \pm 26.16$ \\
XC & P11 & $203.24 \pm 23.75$ & $101.62 \pm 11.88$ & $74.10 \pm 4.16$ \\
XC & P12 & $203.25 \pm 27.60$ & $101.63 \pm 13.80$ & $119.50 \pm 20.40$ \\
\hline Mean & & $174.08 \pm 8.86$ & $87.04 \pm 4.43$ & $152.76 \pm 24.16$ \\
\hline
\end{tabular}

ES $=$ Standard Error

*Allometric equation based on Chave et al. [14].

forests, in Plots (P) 4, 9 and 10 were significantly high compared to other plots. P9 and P10 are dominated by Ce and Lr, respectively, while P4 has an association of Ag with Rm, which is known for a high abundance of relatively large trees in these specific communities. Plots 1, 2 and 5 are not significantly different, but showed significant differences with P4, P9 and P10; the lowest values were observed in P1, P2 and P5, the three plots dominated by Ag, and were the most disturbed. While P3, P6, P7, P8, P11 and P12 showed no significant differences among them. The results of plot 4 were higher than those reported by Fromand et al. [19] in forests with Rhizophora and Avicennia association (143.3 and $122.2 \mathrm{t} \mathrm{C} \mathrm{ha}^{-1}$ ) in French Guyana, the carbon content in the biomass follows the same trend as the AGB. The plots P3, P4, P5 and P6 show the highest values of carbon stored in soil in a range of $202.89 \pm 49.58$ to $480.26 \pm 30.34 \mathrm{t} \mathrm{C} \mathrm{ha}^{-1}$, however, P3 and P4 show significant differences $(\mathrm{p}<0.05$ ) with P5 and P6. This condition can be given because of the high productivity of the species associated with these soils as a result of defoliation, which incorporate a high content of organic matter to soils, in addition to the flooding conditions prevailing at the sites, which induces to store large amounts of carbon. The remaining plots averaged soil carbon of $19.53 \pm 13.18$ to $119.50 \pm$ $20.40 \mathrm{t} \mathrm{C} \mathrm{ha}^{-1}$. It can be inferred that the topographical and hydrological conditions are the cause of these values.

There were differences between the content of carbon stored in the studied plots, mangrove forests are considered as major reservoirs of carbon in their soils, this is influenced by topographical and hydrological conditions, for example, soils with higher waterlogging (P3, P4, P5, P6) had the largest stores of carbon, compared to the driest (P8 and P9), despite having low values of carbon 
content in AGB, P3 and P4 plots showed the higher contents of total carbon, while the lowest at P1 and P8 (fig 4). There are high variations in AGB when comparing different allometric models, this indicates the need to develop allometric models specific to mangrove forests.

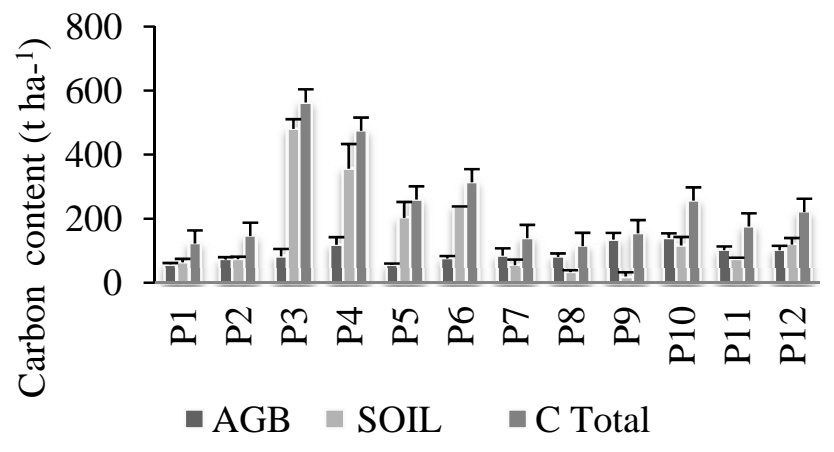

Figure 4: Carbon content in soil and tree biomass (AGB) and the total carbon (C Total) in the different plots for the mangrove forest in Campeche, Mexico. The bars indicate the standard error.

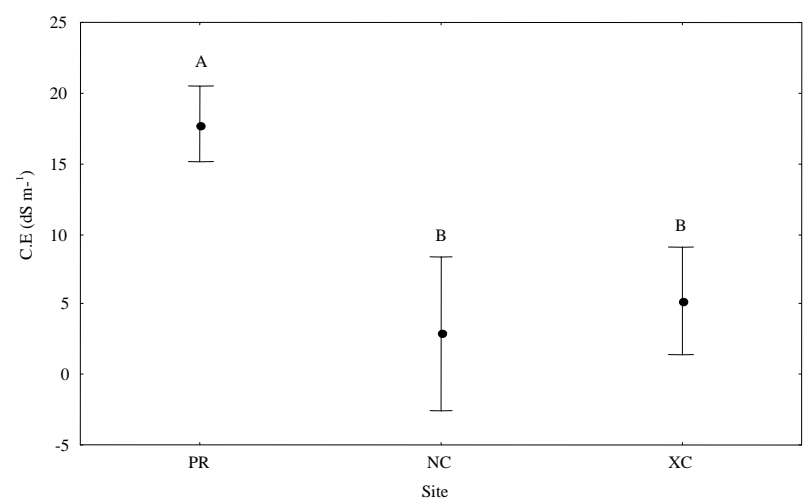

Figure 5: Mean values of EC $\left(\mathrm{dS} \mathrm{m} \mathrm{m}^{-1}\right)$ of the three sites (PR = Puerto Rico, $\mathrm{NC}=\mathrm{New}$ Campechito and $\mathrm{XC}=\mathrm{Xicalango})$. Means with the same letter are not significant.

All sites showed high values of EC $2.93 \pm 0.35,5.18 \pm 0.26$ and $17.78 \pm$ $1.77 \mathrm{dS} \mathrm{m}^{-1}$ to NC, XC and PR, respectively (Figure 5). The EC values are indicators of salinity. Therefore indicate a high salinity for PR, and moderate for $\mathrm{XC}$ and NC, the high salinity in PR is probably attributed to the low permeability of the soil, which contributes to the accumulation of water by increasing the concentrations of $\mathrm{Na}$ and contributing to a low activity of microbiota. It is noteworthy that Ag tolerates higher concentrations of salinity; reason turns out to be the most abundant species at this site. 


\section{Conclusions}

All sites have good potential to store carbon for long periods of time also prevalent in the high productivity of mangrove forests are a source of nutrients that work synergistically with the low rate of decomposition and hydrology, resulting in high storage rates. The maximum content of carbon storage were found in soils at the site of Puerto Rico The results of this study is one of the few measurements of tree biomass and carbon storage in mangrove forests of the humid tropics of Mexico, in particular in the state of Campeche, showing that the soils are good reservoirs of carbon. The AGB values found are influenced by associations of mangrove species present in each of the plots in the study sites. It was found that plots with predominance of Conocarpus erectus showed higher values of AGB while those plots with associations predominating Avicennia germinans showed lower values of tree biomass,

\section{References}

[1] IPCC (Intergovernmental Panel on Climate Change), Climate Change: The Scientific Basis. Cambridge Univ. Press, Cambridge, UK, 2001.

[2] Ordoñez, J.A. and Masera, O. Captura de carbono ante el cambio climático. Madera y Bosques, 7: 3-12, 2001.

[3] Ordoñez, J. A. Captura de carbono en un bosque templado: el caso de San Juan Nuevo, Michoacán 1ra. Edición electrónica. www.ine.gob.mx/ publicaciones/consultaPublicacion.html?id_pub=296 1998.

[4] Komiyama, A., Ong J. E., and Poungparn, S. Allometry, biomass, and productivity of mangrove forests: a review. Aquatic Botany 89: 128-137, 2008.

[5] Whiting, J. G. and Chanton, J. P. Greenhouse carbon balance of wetlands: methane emission versus carbon sequestration. Tellus 53B: 521-528, 2001.

[6] Komiyama, A., Poungparn, S., Kato, S., Common allometric equations for estimating the tree weight of mangroves. J. Trop. Ecol. 21: 471-477, 2005.

[7] INE, Programa de Manejo del área de protección de flora y fauna “Laguna de Términos”; SEMARNAT, 1997.

[8] Lugo, A. and Snedaker, C. 1974. The Ecology of Mangroves. Annual Review of Ecology and Systematics, 5: 38-64.

[9] Twilley, R.W., Lugo, A.E. and Patterson-Zucca, C. Litter Production and Turnover in Basin Mangrove Forests in Southwest Florida. Ecology. 67: 670-683, 1986.

[10] Rico-Gray, V., Estudio de la vegetación de la zona costera inundable del noroeste de Campeche, México: Los petenes. Biótica, 7: 171-188, 1982.

[11] Heiri, O., Lotter, A. F., and Lemcke G. Loss on Ignition as a method for estimating organic and carbonate content in sediments: reproducibility and comparability of results. Journal of paleolimnology 25: 101-110, 2001.

[12] Craft, C. B., Seneca, E.D. and Broome S.W. Ignition and kjeldahl digestion for estimating organic carbon and soils: Calibration with dry combustion. Estuaries. 14: 175-179, 1991. 
[13] Gonzalez, M., Etchevers, B. and Hidalgo, M., Carbono en suelos de ladera: factores que deben considerarse para determinar su cambio en el tiempo. Agrociencia [online]. 42:7, 741-751, 2008.

[14] Chave, J., Andalo, C., Brown, S., Cairns, M.A., Chambers, J.Q., Eamus, D., Fölster, H., Fromard, F., Higuchi, N., Kira, T., Lescure, J.P., Nelson, B.W., Ogawa, H., Puig, H., Riéra, B., and Yamakura, T., Tree allometry and improved estimation of carbon stocks and balance in tropical forests. Oecologia 145: 87-99, 2005.

[15] Zanne, A.E., Lopez, G.G., Coomes, D.A. Llic, J., Jansen, S.L., Lewis, S.L., Miller, R.B., Swenson, N.G., Wiemann, M.C., and Chave, J., Global wood density database. Dryad. Identifier: http://hdl.handle.net/10255/dryad.235, 2009.

[16] Basuki, T.M., van Laake, P.E., Skidmore, A.K. and Hussin, Y. A., Allometric equations for estimating the above-ground biomass in tropical lowland Dipterocarp forest. Forest Ecology and Management, 257: 16841694, 2009.

[17] Day, J.W., Conner, W.H., Ley, L.F., Day, R.H., and Navarro, A.M., The productivity and composition of mangrove forests, Laguna de Terminos, Mexico. Aquat. Bot. 27: 267-284, 1987.

[18] Amarasinghe, M.D., and Balasubramaniam, S., Net primary productivity of two mangrove forest stands on the northwest coast of Sri Lanka. Hydrobiol 247: 37-47, 1992.

[19] Fromard, F., Puig, H., Mougin, E., Marty, G., Betoulle, J.L., Cadamuro, L. Structure above-ground biomass and dynamics of mangrove ecosystems: new data from French Guiana. Oecologia 115: 39-53, 1998.

[20] Mall L.P., Singh V.P. and Garge A., Study of biomass, litter fall, litter decomposition and soil respiration in monogeneric mangrove and mixed mangrove forest of Andaman Island. Trop. Ecol. 32: 144-152, 1991.

[21] Arreaga, W., Carbon storage in forest with a management program in the natural reserve "Maya Peten", Guatemala. Thesis M.Sc. CATIE, Turrialba, CR. 86, 2002.

[22] Webb, A., Pre-clearing soil carbon levels in Australia. National carbon accounting system technical report No. 12. Australian greenhouse office, Canberra, 204, 2002. 